\title{
Contribution of the Diffusion Weighted Magnetic Resonance Imaging on Classification of Hepatic Hydatid Cyst Types
}

\author{
Karaciğer Kist Hidatiklerinin Tiplendirilmesinde Diffüzyon Manyetik Rezonans \\ Görüntüleme Bulgularının Katkısı
}

\author{
(D) Özlem Armay1, (D Ceyda Turan Bektaş2, (D) Aytül Hande Yardımcı², (D Özgür Kılıçkesmez² \\ 1Bitlis State Hospital, Clinic of Radiology, Bitlis, Turkey \\ 2University of Health Sciences, İstanbul Training and Research Hospital, Clinic of Radiology, İstanbul, Turkey
}

\begin{abstract}
Introduction: The purpose of this study is to provide a classification of different types of hepatic hydatid cysts by measuring the mean apparent diffusion coefficient (ADC) and exponential apparent diffusion coefficient (EADC) using diffusion-weighted magnetic resonance imaging (MRI).

Methods: A total of 60 patients (42 female, 18 male) and 79 lesions were included in this retrospective study. The patients were diagnosed with hepatic cyst lesions for various reasons according to the hospital's abdominal MRI records, and therefore all patients had their diagnosis pathologically or serologically confirmed. ADC and EADC maps were obtained with values of $b 0$, and $b 400 \mathrm{~s} / \mathrm{mm}^{2}$, and mean ADC and EADC values were calculated for each lesion. Then, the mean value calculated for each cyst type is compared.

Results: Regarding ADC values, we determined a statistically significant difference between types 1 and 4 , types 2 and 4 , and types 3 and 4 ( $p=0.001)$. When we compared EADC values, we found that EADC values of WHO type 4 lesions were higher than WHO type 1,2 , and 5 lesions $(p=0.001)$. Also, we divided our patients' lesions into two groups, namely active (types $1,2,3$ ) and inactive (types 4,5 ) lesions. When we compared each group's mean ADC and EADC values, we determined a difference between active and inactive groups. When compared to inactive groups, $A D C$ values of active lesions were higher, and EADC values were lower, as shown by statistics.
\end{abstract}

Conclusion: Our study shows that ADC and EADC values may be useful for the differentiation of type 4 lesions from other types, and distinguishing of active and inactive groups.

Keywords: Hydatid cyst, diffusion-weighted magnetic resonance imaging, apparent diffusion coefficient

\section{öz}

Amaç: Bu çalışmada amacımız karaciğerde yerleșmiş olan farklı evrelerdeki kist hidatik lezyonlarının difüzyon ağılıklı görüntüleme (DAG) ile ortalama $A D C$ ve $E A D C$ değerlerini hesaplayarak, lezyonların evrelerine göre birbirinden ayrımında DAG'nin katkısı olup olmayacağını araștırmaktır.

Yöntemler: Çalışmamızda Ocak 2014-Mayıs 2015 tarihleri arasında hastanemizde kist hidatik tanısı almış, patolojik ya da serolojik olarak tanısı doğrulanmış ve herhangi bir sebeple üst batın MR tetkiki yapılmış 18-81 yașları arasında, 60 hastaya (42 kadın, 18 erkek) ait 79 adet lezyon incelendi. b0 ve b400 değerinde elde edilen DAG'den her lezyonun ADC ve EADC haritası çıkarıldı. Daha sonra hidatik kist tiplerinin hesaplanan ortalama ADC ve EADC değerleri kantitatif olarak karşıllaştırılmışır.

Bulgular: Çalışmamızda b400 değerinde, tip 1 ile 4 arasında, tip 2 ile tip 4 arasında, tip 3 ile tip 4 arasında ADC değerleri arasında istatistiksel yönden anlamlı fark olduğu tespit edildi $(p=0,001)$. WHO kategorilerinin EADC değerleri karşılaștırıldığında kategorisi 4 olan hastaların EADC değerleri; WHO kategorisi 1,2,5 olan hastaların ADC değerlerinden anlamlı olarak yüksekti $(p=0,001)$. Ayrıca lezyonları aktif (tip $1,2,3$ ) ve inaktif (tip 4,5) olarak; iki gruba ayırdığımızda grup ortalamaları arasında istatistiksel açıdan anlamlı fark tespit edildi. Aktif lezyonların ADC ortalamaları, inaktif lezyonların $A D C$ ortalamalarından yüksek, EADC ortalamaları, inaktif lezyonların EADC ortalamalarından düşüktü.

Sonuç: Bizim çalıșmamız karaciğer hidatik kist hastalığında tip 4 lezyonların diğer sınıflardan ayırımında ve aktif ve inaktif grupların birbirinden ayırımında $A D C$ ve $E A D C$ değerlerinin faydalı olabileceğini göstermektedir.

Anahtar Kelimeler: Hidatik kist, difüzyon ağırlıklı manyetik rezonans görüntüleme, görünür difüzyon katsayısı
Address for Correspondence/Yazısma Adresi: Özlem Armay MD, Bitlis State Hospital, Clinic of Radiology, Bitlis, Turkey Phone: +90 5357178519 E-mail: ozarmay@hotmail.com ORCID ID: orcid.org/0000-0002-9214-7864

Cite this article as/Atıf: Armay Ö, Turan Bektaș C, Yardımcı AH, Kılıçkesmez Ö. Contribution of the Diffusion Weighted Magnetic Resonance Imaging on Classification of Hepatic Hydatid Cyst Types. İstanbul Med J 2019; 20(6): 547-52.
Received/Geliș Tarihi: 21.01.2019 Accepted/Kabul Tarihi: 22.10.2019 


\section{Introduction}

Hydatid cyst disease is among the most important parasitic zoonosis threatening human and animal health around the world. They are lesions of benign nature and most frequently seen in the liver, although they can be located in almost any part of the body. Diagnostic methods for cystic echinococcosis are imaging, indirect immunological methods, and direct microscopic examination. While imaging methods are prioritized for clinical diagnosis, it is also essential to support it with parasitological and immunological diagnosis in order to make a differential diagnosis of the cyst from other cases such as a tumor, abscess, etc. (1).

Imaging findings of the hydatid cyst disease depend on the development stage of the cyst (2). As imaging findings change depending on the stage of the disease, there is an advantage of using different imaging methods at different stages. Depending on the stage when the disease is diagnosed, the treatment may require medical, surgical, and interventional radiological methods, or it may be enough to monitor the disease.

Ultrasonography (US) is a frequently preferred imaging method in the diagnosis of hydatid cyst disease thanks to its ease of use, noninvasiveness, and easy accessibility. Many classification schemes have been proposed based on the appearance of cysts on US. $(2,3)$ The most frequently used are the classifications of Gharbi and WHO-IWGE (Table 1).

Computed tomography (CT) is highly diagnostic in the spread of the disease, preoperative evaluation of the disease, and detection of the complications if the patient is suspected of clinical, biochemical, and radiological hydatid cyst. Daughter cysts, degenerated membranes, and capsular and peripheral calcifications can be seen on CT. CT is sensitive enough to detect lesion localization and organ spread before the surgery. Additionally, it is superior to the US in visualizing complications $(4,5)$. Unless there are suspected complications such as an opening in the biliary tract and infection, it is not necessary to use intravenous contrast agents (3).

Most of the magnetic resonance imaging (MRI) findings are similar to those identified on CT. This method allows for the precise visualization of the multiloculated or multicystic pattern with a "ring appearance", which can be seen in almost all cases. The ring appearance, considered belonging to the pericyst, causes hypointensity of this collagen-rich layer in T2-weighted sequences. This layer has a ring shape and is generally 2-5 mm in thickness. In some cases, signal loss further increases, and intensity is markedly reduced if there is calcification on the wall. In other epithelial cysts that can be seen in the liver, the wall is not that thick.

\begin{tabular}{|c|c|c|}
\hline Gharbi & WHO & Us characteristics \\
\hline Type1 & CE1 & Unilocular cyst + wall + internal echogenities \\
\hline Type2 & CE3 & Detached membrane \\
\hline Type3 & CE2 & Multivesicular, multiseptated cyst, daughter cysts \\
\hline Type4 & CE4 & Heterogeneous cyst, no daughter vesicles \\
\hline Type5 & CE5 & Cyst with a wall calcification \\
\hline
\end{tabular}

On the other hand, as the hydatid cyst varies according to stages, hepatoma, amoebic abscess, intraparenchymal hematoma, and hepatic adenoma are also considered in the differential diagnosis (6). Another finding that can be identified with MRI is peritumoral edema, which is seen in tumoral lesions but has never been seen in the hydatid cyst disease (7).

Diffusion-weighted imaging (DWI) is a method that can be obtained in a single breath-hold time. It does not require the use of a contrast agent and contributes to diagnosis in cases where benign-malignant differentiation of liver masses cannot be made with conventional sequences (8).

Apparent diffusion coefficient (ADC) maps are obtained in order to measure the diffusion size. Today, exponential ADC (EADC) measurements can also be made with the same systems as a new quantitative indicator. EADC maps allow clinicians to identify the lesion easily, and these maps can also provide quantitative data (9). The exponential map or image is calculated by dividing the diffusion-weighted image with maximum b-value by the b0 image. Mathematically, EADC shows the negative exponential value of $A D C$, and $T 2$ is a diffusion-weighted artificial image with a similar contrast behavior to that of the high b-valued image not having an internal glare effect (10).

\section{Methods}

This study investigated 79 lesions of 60 patients (42 females, 18 males) between the ages of 18-81 who were diagnosed with hydatid cyst disease in our hospital, whose diagnosis was confirmed pathologically or serologically and who underwent upper abdomen MRI due to any reason, between January 2014-May 2015. Lesion classification was made retrospectively under the guidance of USI and T2-weighted images (WI). As they included atypical appearances and calcification, lesions with CT images for WHO type 4 and type 5 lesions were also included in the study. Ethics committee approval was received for this study from the Ethics Committee of Istanbul Training and Research Hospital (decision no: 2015/739).

The conventional MRI and DWI examinations of all cases were made using a 1.5-Tesla superconductive MRI device (Signa HDxt, GE Medical Systems, Milwaukee, Wisconsin, USA) and 8-channel body array coil. The maximum gradient strength of the MR device was $32 \mathrm{mTes} \mathrm{a} / \mathrm{m}$, and the gradient slew rate was $120 \mathrm{mT} / \mathrm{m} / \mathrm{s}$. DWI with b400 value was applied to patients in addition to their T1- and T2-weighted conventional MRI sequences. All of the T1- and T2-WI were applied in the axial and coronal plane.

DWI parameters were as follows; TR/TE: 4800/68 ms; turning angle: $90^{\circ}$; section thickness: $5.5 \mathrm{~mm}$; FOV: $430 \mathrm{~mm}$; NEX: 128x128/4.00. They were obtained by applying diffusion-sensitive gradients on each of the three directions $(x, y, z)$ to the "Single-shot echo-planar" sequence on the 8 Coil body upper/flip axial plane. The first series in the image cluster of the sequence consisted of "Echo-planar-spin echo" T2-WI (b:0); the next three series consisted of images, which were the first series to which diffusion-sensitive gradients were applied separately on $x, y$, and $z$ directions, and isotropic images obtained by calculating the projection of diffusion vectors on three directions. Isotropic images consisted 
of images removing the signal changes depending on the direction, generated by the device by taking the cube root of the multiplication of signal intensities measured on $x, y, z$ directions.

$A D C$ and EADC maps were generated using a software (Functool) on a separate workstation (Advantage Workstation 4.4-GE Medical Systems).

$A D C$ and EADC maps for each lesion were generated from DWI obtained using b0 and b400 values. For numerical evaluation, the measurements were made with a round "Region of Interest" at the largest size possible, away from the artifacts, calcific areas, vascular structures, and healthy tissues, under the guidance of T2-WI (Figure 1). By taking the average of $A D C$ and EADC measurements of at least two consecutive sections for each lesion and three for large lesions, mean values were calculated for that lesion. Then, the mean ADC and EADC values of hydatid cyst types were quantitatively compared.

\section{Statistical Analysis}

When evaluating the results of the study, SPSS 21.0 statistical package was used for statistical analyses. When evaluating the study data, descriptive statistical methods (number, percentage, mean, standard deviation, median, minimum, maximum) were used. Pearson's chisquare test was used to compare qualitative data.

Regarding quantitative data, the Mann-Whitney $U$ test was used to compare the parameters between two groups. Regarding multigroup comparison for quantitative data, the Kruskal-Wallis test was used to compare the parameters between the groups, and the Mann-Whitney $U$ test was used to detect the group causing the difference. As there was a significant difference in the Mann-Whitney $U$ test following the KruskalWallis variance analysis, the significance threshold was determined as 0.005 after Bonferroni correction. Other results were evaluated in a $95 \%$ confidence interval with a significance level of $p<0.05$.

\section{Results}

A total of 60 patients (42 female, 18 male) and 79 lesions were included in the research. The subjects were diagnosed with hepatic cystic lesions for various reasons according to the hospitals archived records of abdominal MRI between January 2014 and May 2015, therefore they had their diagnosis pathologically or serologically confirmed. Lesions were classified according to WHO-IWGE using the US, CT, and MRI images in the system. Eight of the cases (10.1\%) were 1.18 (22.8\%) were 2.22 (27.8\%) were 3.19 (24.1\%) were 4.12 (15.2\%) were 5.

Forty-three of the patients (72\%) were female, and 17 (28\%) were male. The mean age of the patients was $46.2 \pm 17.2$ years (range: 18-81). The presence of a statistically significant age-related difference between the WHO categories was investigated using the Kruskal-Wallis variance analysis, and no difference was found $(p=0.298)$. To evaluate the difference between the genders concerning WHO Categories, Pearson's chi-square analysis was used, and no significant difference was found $(p=0.431)$.

The size variable consisted of the two longest different values. These two values were multiplied to calculate the mass volume. When the mass volumes of WHO categories were compared, there was no statistically significant difference $(p=0.079)$. Using the maximum value measured for the size variable, the maximum mass measurement was calculated. When the maximum mass measurements of the WHO categories were compared, no statistically significant difference was found ( $p=0.103$ ).

In our study, $\mathrm{ADC}$ values using the b400 value were calculated to be: $3.20 \times 10^{-3} \mathrm{~s} / \mathrm{mm}^{2}$ for type 1 lesions, $3.06 \times 10^{-3} \mathrm{~s} / \mathrm{mm}^{2}$ for type 2 lesions, $3.49 \times 10^{-3} \mathrm{~s} / \mathrm{mm}^{2}$ for type 3 lesions, $2.33 \times 10^{-3} \mathrm{~s} / \mathrm{mm}^{2}$ for type 4 lesions, and $2.58 \times 10^{-3} \mathrm{~s} / \mathrm{mm}^{2}$ for type 5 lesions. We detected no statistically significant difference in terms of ADC values between type 1 and 4 ; type 2 and type 4 ; and type 3 and type $4(p=0.001)$ (Figure 2).

EADC values using the b400 value were calculated to be: $1.91 \times 10^{-2} \mathrm{~s} / \mathrm{mm}^{2}$ for type 1 lesions, $2.69 \times 10^{-2} \mathrm{~s} / \mathrm{mm}^{2}$ for type 2 lesions, $2.74 \times 10^{-2} \mathrm{~s} / \mathrm{mm}^{2}$ for type 3 lesions, $3.92 \times 10^{-2} \mathrm{~s} / \mathrm{mm}^{2}$ for type 4 lesions, and $2.92 \times 10^{-2} \mathrm{~s} /$ $\mathrm{mm}^{2}$ for type 5 lesions. There was a statistically significant difference found when EADC values of WHO categories were compared $(p=0.001)$. Therefore, the EADC values of patients with WHO category of 4 were higher than that of the patients with WHO categories of 1, 2, 5 (Figure 3).

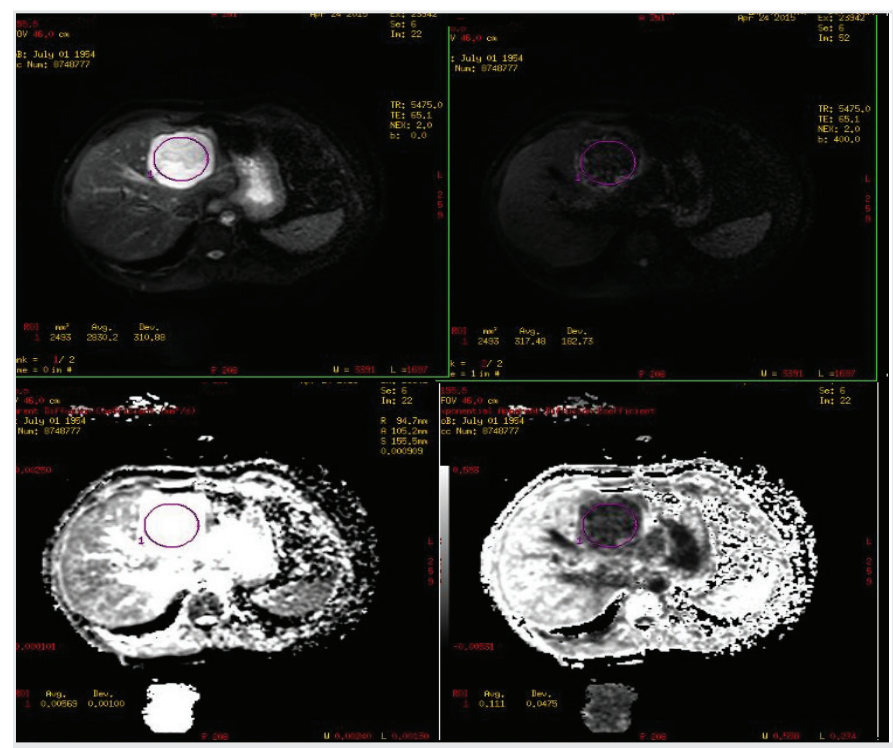

Figure 1. Image of the CE3 hydatid cyst lesion using b0 and b400 values measurements made from the ADC and EADC maps

ADC: apparent diffusion coefficient, EADC: exponential apparent diffusion coefficient

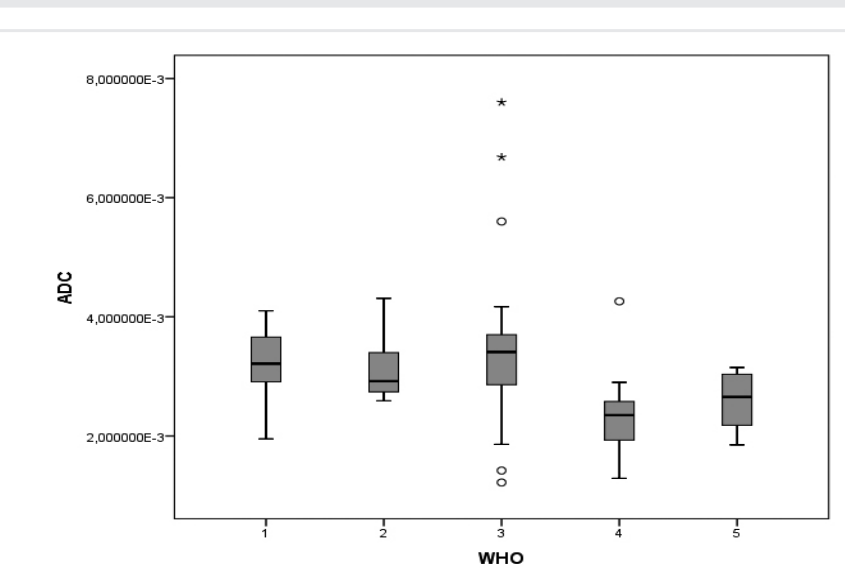

Figure 2. Apparent diffusion coefficient distribution by groups ADC: apparent diffusion coefficient 
In order to determine whether ADC means showed a statistically significant difference according to the lesion type, we divided the lesions into two groups as active (type 1,2,3) and inactive (type 4,5) lesions. There was a statistically significant difference between the group means (Mann-Whitney $U=291.500 ; p=0.000, p<0.05)$. ADC means of the active lesions (0.003) were higher than that of the inactive lesions (0.002).

When the presence of a significant difference between the EADC means of the patients concerning the lesion type variable was investigated, the difference between the group means was found to be statistically significant (Mann Whitney U test: 407.000; $p=0.001<0.05$ ). EADC means of the active lesions (0.259) were lower than that of the inactive lesions (0.354) (Table 2).

Furthermore, during the evaluation regarding whether there was a significant difference between the mass volume mean values of the patients according to the lesion type variable, there was a statistically significant difference between the group means (MannWhitney $U=543.500 ; p=0.044<0.05)$. The mass volume means of the active lesions (3834.080) were higher than that of the inactive lesions (2238.970).

When the presence of a significant difference between the maximum mass measurement means of the patients concerning the lesion type variable was investigated, the difference between the group means was found to be statistically significant (Mann-Whitney $U=506.500 ; p=0.028$ $<0.05)$. The maximum mass volume means of the active lesions (63.188) were higher than that of the inactive lesions (46.800).

\section{Discussion}

MRI is one of the most important radiological diagnostic methods used in the detection and characterization of liver lesions (10). In recent years,

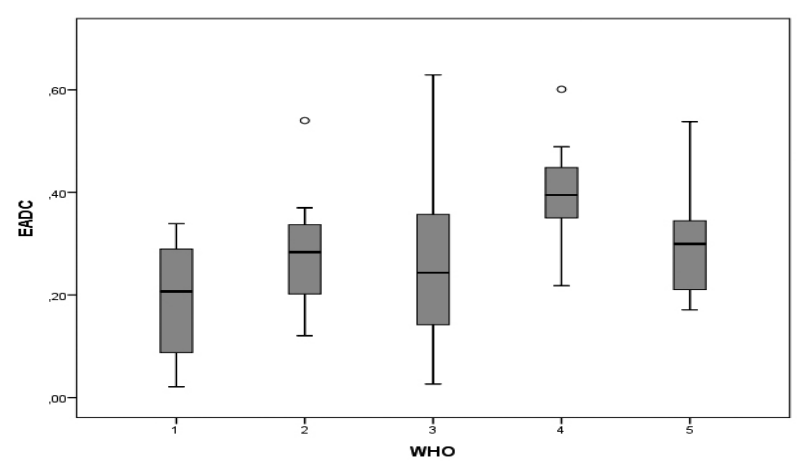

Figure 3. Exponential apparent diffusion coefficient distribution by groups EADC: exponential apparent diffusion coefficient

Table 2. ADC and eADC values for determining active and inactive lesions

\begin{tabular}{|c|c|c|c|c|c|c|}
\hline & \multicolumn{2}{|c|}{ Live lesion } & \multicolumn{2}{|c|}{ Dead lesion } & \multirow{2}{*}{ MW } & \multirow{2}{*}{$\mathbf{p}$} \\
\hline & Mean & SD & Mean & SD & & \\
\hline$A D C$ & 0.003 & 0.001 & 0.002 & 0.001 & 291.500 & 0.000 \\
\hline EADC & 0.259 & 0.144 & 0.354 & 0.108 & 407.000 & 0.001 \\
\hline Mass volume & 3834.080 & 3604.286 & 2238.970 & 2168.429 & 543.500 & 0.044 \\
\hline Maximum mass measurement & 63.188 & 33.761 & 46.800 & 21.188 & 506.500 & 0.028 \\
\hline
\end{tabular}

the DWI examination, a technique not requiring the use of a contrast agent, has entered into use in the imaging of abdominal organs and has contributed considerably to lesion characterization (10-12).

DWI sequence is a method that can be obtained in a single breath-hold time, does not require the use of a contrast agent, and contributes to diagnosis in cases where benign-malignant differentiation of liver masses cannot be made in conventional sequences (8). Quantitative measurement of diffusion is possible today with ADC measurements.

High intensity of cell membranes in tissues with high cellularity like tumor tissues limits the diffusion of water protons. On the contrary, water molecules move more easily in cystic or necrotic tissues, and ADC of the water protons are identified as free. Therefore, diffusion MRI provides information about tissue cellularity and the integrity of cellular membranes. ADC value is the first one to be affected during the intracellular liquid increase resulting from the disruption in membrane permeability. The presence of the diffusion is observed as signal loss and in turn, a high value of ADC. On the other hand, limited diffusion in the tumor cell emerges in DWI with high signal intensity and in turn, low $A D C$ values (8). Several studies in the literature demonstrate that ADC measurements are beneficial in the benign-malign differentiation of the lesions of the liver (8,10-12).

Today, EADC measurements can also be done by using ADC maps as a new quantitative indicator, which is the mathematically negative exponential value of ADC, with which the T2 glare effect is removed, and lesion visualization is increased $(9,10)$. There are studies showing that EADC maps are beneficial in lesion identification similar to ADC and in some cases, even superior to $\operatorname{ADC}(13,14)$.

While hepatic hydatid cyst is a benign condition unless any complication develops, it is sometimes difficult to differentiate between stage 4 lesions and other liver masses because of them not having a pathognomonic radiologic appearance.

Although there is no study conducted using the b400 value, Oruç et al. (15) study measured ADC values using b0, b50 and b1000 values and investigated the role of DWI in the classification of hydatid cysts and differentiation between simple cysts and abscesses but found no significant difference related to $b$ values. The study, which used the Gharbi classification, reported a statistically significant difference in ADC values of type 4 hydatid cysts compared to type 1 and type 3 hydatid cysts, similar to our study. This study did not include type 2 hydatid cysts due to the small number of lesions and type 5 lesions due to their calcifications, but they also concluded that DWI did not have a significant contribution to the differentiation of type 1 lesions from simple liver 
cysts. As MRI has some shortcomings in calcification imaging, the present study included type 5 lesions provided that there was a CT test conducted, and we found no statistically significant difference in the differentiation from other types except type 4 lesions.

Another study by Ceçe et al. (16) investigated the role of DWI in the classification of the hydatid cysts of the liver. The examination used the mean ADC maps generated from the measurements using b0, b500, and b1000 values in 44 lesions of 44 patients, which included 15 type 1, 11 type 2, 7 type 3, 5 type 4 , and 6 type 5 according to the Gharbi classification. While this study did not evaluate the difference between $b$ values, the mean $\mathrm{ADC}$ values were determined as follows: $2.48 \times 10^{-3}$ $\mathrm{mm}^{2}$ for type $1 ; 2.8010^{-3} \pm 0.34 \mathrm{~s} / \mathrm{mm}^{2}$ for type $2 ; 2.7010^{-3} \pm 0.26 \mathrm{~s} / \mathrm{mm}^{2}$ for type $3 ; 2.02 \times 10^{-3} \pm 0.01 \mathrm{~s} / \mathrm{mm}^{2}$ for type 4 ; and $2.18 \times 10^{-3} \pm 0.1 \mathrm{~s} / \mathrm{mm}^{2}$ for type 5 . In the study, type 4 hydatid cysts could be differentiated from all other groups in the confidence interval of $95 \%$, and the study claimed that they could be detected with $100 \%$ sensitivity and $100 \%$ specificity when the threshold value was taken as $\leq 2.06 \times 10^{-3}$ for type 4 lesions. They also argued that type 1 lesions could be differentiated from type 2, type 4 and type 5; type 2 lesions from type 1, 4 and 5; type 3 lesions only from type 4; and type 4 lesions from 1, 2, 3, 5; and type 5 lesions from type 1, 2, and 4 (16).

Also, when two groupings were made as type 1, 2, 3 lesions and type 4, 5 lesions, diffusion MRI was found to be "excellent" in the differentiation of these two groups (16).

Koken et al. (17) study investigated 92 lesions of 54 patients by creating $A D C$ maps using b50, b500, and b1000 values. When the ADC values were compared according to lesion groups, there was no significant difference between type 1 and 2, 3; type 2 and 3; type 3 and 4; or type 4 and 5.

Similar to our study, Koken et al. (17) suggested that a comparison of hydatid cyst types according to ADC values could be beneficial in the differentiation of type 1, 2, and 3 from type 4 and 5 .

Another study by Sonmez et al. (18) retrospectively investigated 28 hydatid cysts and 22 simple cysts larger than at least $1 \mathrm{~cm}$. Sixteen of lesions were type 1 , and 12 were type 3., and there was no statistical difference between ADC values of lesions. Similar to Sonmez et al. (18), our study did not find any significant difference between type 1 and type 3 lesions classified according to Gharbi.

Hydatid cysts are lesions of benign nature, most frequently seen in the liver (1). Type 1, 2, and 3 cysts, according to both classifications, show a treatment indication. In recent years, percutaneous treatment of these lesions using the US (PAIR) has been preferred considering the surgery and the risks thereof. Also, some of the studies in the literature indicate that percutaneous treatment can be applied to type 4 lesions depending on the liquid component amount it contains (18-22).

The limitations of our study included having a retrospective design, less CE type 1 and CE type 5 lesions compared to other groups, and using only b0 and b400 values for ADC measurements. Although other studies in the literature detected no significant difference based on $b$ values (15), we think that this may be open to further research and new developments as the number of related studies is limited. Furthermore, the susceptibility weighted sequence in MRI is also included in the evaluation of calcifications today, but the retrospective nature of our study did not allow us to include it in the present research.

\section{Conclusion}

Our study shows that ADC and EADC values can be beneficial in the differentiation of type 4 lesions from other classes, and active and inactive groups in hydatid cysts of the liver.

$A D C$ and EADC values are also important in the differentiation of active and inactive lesions. ADC values of inactive lesions (CE type 4 and 5) were significantly lower than the CE type 1, 2, and 3 lesions, which are considered to be active.

Ethics Committee Approval: Ethics committee approval was received for this study from the Ethics Committee of İstanbul Training and Research Hospital (decision no: 2015/739).

Informed Consent: Retrospective study.

Peer-review: Externally peer-reviewed.

Author Contributions: Surgical and Medical Practices - Ö.A.; Concept Ö.A., C.T.B., A.H.Y., Ö.K.; Design - Ö.A., C.T.B., A.H.Y., Ö.K.; Data Collection and/or Processing - Ö.A.; Analysis and/or Interpretation - Ö.A.; Literature Search - Ö.A.; Writing Manuscript - Ö.A.

Conflict of Interest: No conflict of interest was declared by the authors.

Financial Disclosure: The authors declared that this study received no financial support.

\section{References}

1. Pawłowski ZS, Eckert J, Vuitton DA et al. Echinococcosis in humans: Clinical aspects, diagnosis and treatment. In: Eckert J, Gemmell MA, Meslin F-X, Pawlowski ZS (eds). WHO/OIE Manual on echinococcosis in humans and animals: A Public Health Problem of Global Concern. World Health Organization, Geneva, 2001; 20-71.

2. Pedrosa I, Saiz A, Arrazola L. Hydatid disease: radiologic and pathologic features and complications. Radiographics 2000; 20: 795-17.

3. de Diego J, Lecumberri FJ, Franquet T. Computed tomography in hepatic echinococcosis. AJR Am J Roentgenol 1982; 139: 699-2.

4. de Diego Choliz J, Lecumberri Olaverri FJ, Franquet Casas T, Ostiz Zubieta S. Computed tomography in hepatic echinococcosis. AJR Am J Roentgenol 1982; 139: 699-702.

5. Czermak B, Akhan O, Hiemetzberger R, Zelger B. Echinococcosis of the liver. Abdominal imaging 2008; 33: 133-43.

6. Beggs I. The radiological appearances of hydatid disease of the liver. Clin Radiol 1983; 34: 555-63.

7. Morris DL, Buckley C, Gregson R. MR in hydatid disease. Clinic Radiol 1987; 338: 1-41.

8. Aybar MD, Karagöz Y, Turna Ö. The contribution of diffusion weighted MRI (DWI) and measured ADC values in differentiating benign and malignant liver Masses. İstanbul Med J 2013; 14: 16-9.

9. Zhang Y-L, Yu B-L, Ren J, Qu K, Wang K, Qiang YQ, et al. EADC Values in diagnosis of renal lesions by $3.0 \mathrm{~T}$ diffusion-weighted magnetic resonance imaging: Compared with the ADC Values. Appl Magn Reson 2013; 44: 349-63.

10. Demir OI, Obuz F, Sağol O. Contribution of diffusion-weighted MRI to the differential diagnosis of hepatic masses. Diagn Interv Radiol 2007; 13: 81-6. 
11. Yoshikawa T, Kawamitsu H, Mitchell DG. ADC measurement of abdominal organs and lesions using parallel imaging technique. AJR Am J Roentgenol 2006; 187: 1521-3.

12. Ichikawa T, Haradome H, Hachiya J. Diffusion-weighted MR imaging with a single-shot echoplanar sequence: Detection and characterization of focal hepatic lesions. AJR Am J Roentgenol 1998; 170: 397-402.

13. Sprinkart AM, Marx C, Träber F, Block W, Thomas D, Schild H, et al. Evaluation of exponential ADC (eADC) and computed DWI (CDWI) for the detection of prostate cancer. Rofo 201; 190: 758-66.

14. Kothari S, Singh A, Das U, Sarkar DK, Datta C, Hazra A. Role of exponential apparent diffusion coefficient in characterizing breast lesions by 3.0 Tesla diffusion-weighted magnetic resonance imaging. Indian J Radiol Imaging 2017; 27: 229-36.

15. Oruç E, Yıldırım N, Topal NB, Kılıçturgay S, Akgöz S, Savcı G. The role of diffusion-weighted MRI in the classification of liver hydatid cysts and differentiation of simple cysts and abscesses from hydatid cysts. Diagn Interv Radiol 2010; 16: 279-87.

16. Ceçe H, Gündoğan M, Karakaș O, Karakaș E, Boyacı FN, Yıldız S, et al. The role of diffusion-weighted magnetic resonance imaging in the classification of hepatic hydatid cysts. Eur J Radiol 2013; 82: 90-4.
17. Koken D, Cagli B, Tuncel SA, Sengul E, Yilmaz E, Unlu ME. Efficacy of diffusionweighted MRI in the differentiation of all liver hydatid cyst types. J Med Imaging Radiat Oncol 2016; 60: 59-65.

18. Sonmez G, Sivrioglu AK, Mutlu H, Ozturk E, Incedayi M, Karaman B, et al Is it possible to differentiate between hydatid and simple cysts in the liver by means of diffusion-weighted magnetic resonance imaging? Clin Imaging 2012; 36: 41-5.

19. Men S, Hekimoğlu B, Yücesoy C, Arda IS, Baran I. Percutaneous treatment of hepatic hydatid cysts. An alternative to surgery. AJR Am J Roentgenol 1999; 172: 83-9.

20. Akhan O, Ozmen MN, Dinçer A, Sayek I, Göçmen A. Liver hydatid disease long-term results of percutaneous treatment. Radiology 1996; 198: 259-64.

21. Ustünsöz B, Akhan O, Kamiloğlu MA, Somuncu I, Uğurel MS, Cetiner S Percutaneous treatment of hydatid cysts of the liver: long-term results. AJR Am J Roentgenol 1999; 172: 91-6.

22. Khuroo MS, Zargar SA, Mahajan R. Echinococcus granulosus cysts in the liver: management with percutaneous drainage. Radiology 1991; 180: 141-5. 